\title{
Al6061 Hybrid Metal Matrix Composite Reinforced with Alumina and Molybdenum Disulphide
}

\author{
G. Pitchayyapillai, ${ }^{1}$ P. Seenikannan, ${ }^{1}$ K. Raja, ${ }^{2}$ and K. Chandrasekaran ${ }^{3}$ \\ ${ }^{1}$ Department of Mechanical Engineering, Sethu Institute of Technology, Kariapatti, Tamil Nadu, India \\ ${ }^{2}$ Department of Mechanical Engineering, University College of Engineering, Anna University, Dindigul, Tamil Nadu, India \\ ${ }^{3}$ Department of Mechanical Engineering, MAM School of Engineering, Trichy, Tamil Nadu, India
}

Correspondence should be addressed to G. Pitchayyapillai; gp_pillai05@yahoo.com

Received 1 September 2016; Accepted 12 October 2016

Academic Editor: Luigi Nicolais

Copyright (C) 2016 G. Pitchayyapillai et al. This is an open access article distributed under the Creative Commons Attribution License, which permits unrestricted use, distribution, and reproduction in any medium, provided the original work is properly cited.

\begin{abstract}
Aluminum Hybrid Reinforcement Technology is a response to the dynamic ever-increasing service requirement of industries such as transportation, aerospace, automobile, and marine, due to its attractive properties like high ductility, highly conductivity, light weight, and high strength to weight ratio. In this evolution, an attempt has been made to investigate the wear rate of Al6061 hybrid metal matrix composite reinforced with the hard ceramic alumina $\left(4,8\right.$, and $\left.12 \mathrm{wt} . \% \mathrm{of}_{2} \mathrm{Ol}_{3}\right)$ and soft solid lubricant of molybdenum disulphide $\left(2,4\right.$, and $6 \mathrm{wt} . \%$ of $\left.\mathrm{MoS}_{2}\right)$ is fabricated by using stir casting method. The unlubricated pins on disc wear tests were conducted to examine the wear behaviour of Al6061/12 wt.\% of $\mathrm{Al}_{2} \mathrm{O}_{3} / \mathrm{MoS}_{2}$ composites. The sliding wear tests were carried out at various loads of 15,30 , and $45 \mathrm{~N}$, sliding velocity $(1.25,2.50$, and $3.25 \mathrm{~m} / \mathrm{sec})$, and different $\mathrm{MoS}_{2}$ wt. $\%(2,4$, and 6 wt.\%). In addition, the CNC turning experiments were conducted on Al6061/12 wt.\% $\mathrm{Al}_{2} \mathrm{O}_{3} / 6$ wt.\% $\mathrm{MoS}_{2}$ using CNMG 120408 uncoated carbide cutting tool under cutting of 100,150 , and $200 \mathrm{~m} / \mathrm{min}$, feed of $0.1,0.2$, and $0.3 \mathrm{~mm} / \mathrm{rev}$, and depth of cut of $1,1.5$, and $2 \mathrm{~mm}$.
\end{abstract}

\section{Introduction}

Aluminum hybrid matrix composites have become better substitutes for the conventional aluminum alloys because of their characters like improved strength to weight ratio, energy saving, and better wear resistance [1]. Reinforced aluminum hybrid matrix, a composite for the use of the automotive industry and other structural applications, has been increased because of the physical and mechanical properties it possesses [2]. Aluminum based hybrid matrix composites with a variety of particulate reinforcements such as $\mathrm{Al}_{2} \mathrm{O}_{3}, \mathrm{TiC}, \mathrm{Ti}_{2} \mathrm{~B}, \mathrm{~B}_{4} \mathrm{C}$, $\mathrm{TiN}, \mathrm{Si}_{3} \mathrm{~N}_{4}$, graphite, and industrial waste byproduct have been conceived and developed for various potential applications [3]. Researchers have developed aluminum hybrid matrix composites and they are used in many commercial and industrial applications [4]. Newer compositions have been continuously explored and the related valuable studies presented by the past researchers were discussed. Veeresh Kumar et al. [5] conducted the experiment on Al6061/SiC and $\mathrm{Al} 7075 / \mathrm{Al}_{2} \mathrm{O}_{3}$ metal matrix composites and presented the experimental results of the studies regarding hardness, tensile strength, and wear resistance properties of $\mathrm{Al} 6061 / \mathrm{SiC}$ and $\mathrm{Al} 7075 / \mathrm{Al}_{2} \mathrm{O}_{3}$ composites. The $\mathrm{SiC}$ and $\mathrm{Al}_{2} \mathrm{O}_{3}$ resulted in improving the hardness and density of their respective composites.

Anilkumar et al. [6] have conducted the mechanical properties of fly ash reinforced Al6061 composites and found that the tensile strength, compressive strength, and hardness of the Al6061 composites decrease with the increase in particle size of reinforced fly ash. Increase in the weight fractions of the fly ash particles increases the ultimate ensile strength, compressive strength, and hardness and decreases the ductility of the composite. Asif et al. [7] have investigated the development of aluminum based hybrid metal matrix composites for heavy duty applications and investigated the dry sliding wear behaviour of aluminum alloy based composites, reinforced with silicon carbide particles and solid lubricants such as graphite/antimony trisulphide. The results 
revealed that wear rate of hybrid composites is lower than the binary composite. The wear rate decreases with the increasing load and increases with increasing speed.

Singh et al. [8] have conducted an experimental investigation on mechanical behaviour of aluminum by adding $\mathrm{SiC}$ and alumina. This work was focused on studying the change in behaviour of aluminum by adding a different percentage age amount of $\mathrm{SiC}$ and $\mathrm{Al}_{2} \mathrm{O}_{3}$ composite and it was concluded that the mechanical properties such as hardness, yield strength, and ultimate strength increasing with a weight percentage of reinforcement increase. But at the same time elongation is decreased and the behaviour of material is changed from ductile to brittle. Gaitondel et al. [9] have done an experiment on wear and corrosion properties of $\mathrm{Al} / \mathrm{Al}_{2} \mathrm{O}_{3}$ /graphite hybrid composites. The effects of reinforcement, time duration, and particle size on prepared samples of composites have been studied on slurry erosive wear. The static and accelerated corrosion tests have been performed and the microhardness of the developed composites was also investigated. The experimental results on $\mathrm{Al} 5083 / \mathrm{Al}_{2} \mathrm{O}_{3} /$ graphite hybrid composites revealed that the addition of reinforcement improves the hardness and reduces corrosion and wear rates.

Sharanabasappa and Motgi [10] were conducting experiments on mechanical properties of fly ash and alumina reinforced aluminum alloy composites. The mechanical properties of fly ash and alumina reinforced aluminum alloy (LM25) composite samples, processed by stir casting route, were reported. It was found that the tensile strength and hardness of the aluminum alloy composites increase with the increase in \%wt. of $\mathrm{Al}_{2} \mathrm{O}_{3}$. Kuma and Singh [11] investigated a comparative investigation of mechanical properties of aluminum based hybrid metal matrix composites. The result indicated that there is an increase in the value of tensile strength, ultimate tensile strength, hardness value, and flexural strength of newly developed composite having $\mathrm{SiC}$ and $\mathrm{B}_{4} \mathrm{C}$ particulates in comparison to the $\mathrm{SiC}$, graphite reinforced composite.

Wang and Yan [12] investigated the feasibility of machining $\mathrm{Al} 6061 / \mathrm{Al}_{2} \mathrm{O}_{3}$ composite materials by electro discharge machining for blind hole drilling and evaluated the material removal rate, tool wear rate, and surface roughness with various input parameters. Yan and Wang [13] observed that material removal rate is increased with peak current and was erratic with pulse duration. The material removal rate, tool wear rate, and surface roughness are increased with flushing pressure during machining of $\mathrm{Al} 6061 / \mathrm{Al}_{2} \mathrm{O}_{3}$ composites using rotary electro discharge machining with a tube electrode. Yan et al. [14] found that, in case of rotary electro discharge machining process, the main challenge is using a disk like electrode for machining $\mathrm{Al} 6061 / \mathrm{Al}_{2} \mathrm{O}_{3}$ composites. The influence of reinforcement of $\mathrm{SiC}$ and $\mathrm{Al}_{2} \mathrm{O}_{3}$ in different matrix of Al6061 and Al7075 on mechanical properties was investigated by Veeresh kumar et al. [15] and they found that microhardness of the composites was increased linearly with the increase of filler content. The surface roughness increases with increase in volume fraction of $\mathrm{Al}_{2} \mathrm{O}_{3}$ particles reinforced with aluminium metal matrix composites when machined by carbide coated tools [16].
The cutting velocity has $20.8 \%$ influences on the surface roughness during machining of A356/20/SiC/T6 composite [17]. Better surface finish was achieved while machining aluminum metal matrix composites with 5\% SiCp at higher cutting speed produces [18]. Metin Kok [19] concluded that while machining $\mathrm{Al} 2024 / \mathrm{Al}_{2} \mathrm{O}_{3}$ composites using coated and uncoated carbide cutting tools the surface roughness of the work piece was mostly affected by cutting speed. The machined surfaces of Al-Si alloy-graphite composites tend to be rougher than the surfaces machined at identical conditions on matrix material without reinforcement because of the presence of deeper holes or valleys [20]. The surface roughness value decreases with increasing cutting speed.

However many researchers have carried out the mechanical and wear properties and machining characteristics of aluminum metal matrix composites with $\mathrm{SiC}$ and $\mathrm{Al}_{2} \mathrm{O}_{3}$ as reinforcing materials. In the case of hybrid Al6061/ $\mathrm{Al}_{2} \mathrm{O}_{3} / \mathrm{MoS}_{2}$ composites, limited literature is available, encompassing various aspects such as mechanical properties and wear behaviour and conducting the machining study of the composites. Aluminum based $\mathrm{Al}_{2} \mathrm{O}_{3}$ composite material has properties such as low weight, heat resistant, wear resistant, and low cost. These are found in various engineering applications such as cylinder block liners, vehicle drive shafts, automotive pistons, and bicycle frames. These materials are known as difficult to machine materials, because of the hardness and abrasive nature of reinforcement element like alumina particle [21]. The addition of $\mathrm{MoS}_{2}$ reinforcement in composites as a hybrid reinforcement further increases the wear resistance of the composite. This is attributed to the stable and $\mathrm{MoS}_{2}$ rich mechanically mixed layer, which prevents metal to metal contact and reduces the wear of the composite. The unstable mechanically mixed layer in the absence of the lubricant phase leads to lower wear resistance in hybrid composite [22]. So an attempt was made to study the tribological, mechanical, and machining characteristics on $\mathrm{Al} 6061 / \mathrm{Al}_{2} \mathrm{O}_{3} / \mathrm{MoS}_{2}$ hybrid composite.

\section{Experimental Details}

The stir casting method is simple and the most economical way of fabricating particulate reinforced composites. In this technique, to accomplish the optimum properties of the hybrid composites, the distribution of the reinforced particles in the base material should be homogeneous and the wettability among the olden materials and particulates ought to be optimized. The moisture level in the cast composite must be reduced and the element reactions among the particles and the base material have to be avoided. The whirlpool method is one of the enhanced recognized tactics used to build a high quality allocation of the reinforced material in the base matrix. In this method, the base material is melted followed by a forceful stirring by automatic agitator to form a whirlpool at the face of dissolve, and the particle is subsequently introduced at the region of the vortex.

2.1. Material Fabrication. The chemical composition of Al6061 alloy is given in Table 1 and Al6061 alloy was 
TABLE 1: Chemical composition of Al6061 alloy.

\begin{tabular}{lcccccccc}
\hline $\mathrm{Si}$ & $\mathrm{Fe}$ & $\mathrm{Cu}$ & $\mathrm{Mn}$ & $\mathrm{Mg}$ & $\mathrm{Cr}$ & $\mathrm{Zn}$ & $\mathrm{Ti}$ & $\mathrm{Al}$ \\
0.65 & 0.7 & 0.25 & 0.15 & 0.8 & 0.07 & 0.25 & 0.15 & Remaining \\
\hline
\end{tabular}

TABLE 2: Affecting factors and levels selected for tensile strength Al6061/ $\mathrm{Al}_{2} \mathrm{O}_{3} / \mathrm{MoS}_{2}$.

\begin{tabular}{lllc}
\hline Factors/levels & 1 & 2 & 3 \\
$X:$ wt.\% $\mathrm{Al}_{2} \mathrm{O}_{3}$ (wt.\%) & 4 & 8 & 12 \\
$Y:$ wt.\% $\mathrm{MoS}_{2}$ (wt.\%) & 2 & 4 & 6 \\
\hline
\end{tabular}

melted in a crucible furnace at $725^{\circ} \mathrm{C}$. Subsequent to melting and degassing by nitrogen, the molten metal was stirred by an alumina coated stainless steel stirrer at $600 \mathrm{rpm}$ for 20 min time duration. During stirring, it is preheated at $600^{\circ} \mathrm{C}$; particles alumina and $\mathrm{MoS}_{2}$ powder were added. After the addition of $\mathrm{MoS}_{2}$, the composite was poured into the preheated $\left(250^{\circ} \mathrm{C}\right)$ permanent mould. The Al6061 alloy with different wt.\% of hybrid composites is produced and test specimens were machined according to ASTM standards.

2.2. Mechanical Behaviour. The hardness tests were carried out according to ASTM E10-07 standards using Brinell hardness testing machine with a $10 \mathrm{~mm}$ ball indenter and $500 \mathrm{~kg}$ load for $30 \mathrm{sec}$. The test was carried out at atmospheric temperature $\left(30^{\circ} \mathrm{C}\right)$ and the measurement of hardness was taken at three different locations on each sample to obtain an average value of hardness. As per the ASTM E08-8 standard, the tensile strength was evaluated on the cylindrical rod of casted composites. The 1200 grit grindings silicon carbide paper was used to polish the test specimens in order to decrease the machining scratches and the effects of surface defects on the sample. The universal testing machine was loaded with $10 \mathrm{KN}$; load cell was used to conduct the tensile test. The affecting factors and levels selected for mechanical behaviour $\mathrm{Al} 6061 / \mathrm{Al}_{2} \mathrm{O}_{3} / \mathrm{MoS}_{2}$ are given in Table 2 .

2.3. Tribological Behaviour. Dry sliding wear behaviour of Al6061/12 wt. $\% \mathrm{Al}_{2} \mathrm{O}_{3} / \mathrm{MoS}_{2}$ hybrid composites is studied in pin on disc test apparatus. Pin specimens of $6 \mathrm{~mm}$ diameter and $15 \mathrm{~mm}$ height, for wear test, were prepared from the above composites and the composites were machined and polished. The test was conducted with various loads of $15 \mathrm{~N}, 30 \mathrm{~N}$, and $45 \mathrm{~N}$ at a sliding speed of 125, 2.50, and $3.25 \mathrm{~m} / \mathrm{s}$ and 2,4 , and $6 \mathrm{MoS}_{2}$ wt.\%. It was conducted at room temperature $\left(30^{\circ} \mathrm{C}\right)$ and relative humidity of $60-65 \%$. The affecting factors and levels selected for Tribology Al6061/12 wt. $\% \mathrm{Al}_{2} \mathrm{O}_{3} / \mathrm{MoS}_{2}$ are given in Table 3.

2.4. CNC Turning Test. The work material used for the present investigation is Al6061/12 wt.\% $\mathrm{Al}_{2} \mathrm{O}_{3} / 6$ wt.\% $\mathrm{MoS}_{2}$ and diameter of the material is $20 \mathrm{~mm}$ and machined length is $60 \mathrm{~mm}$ for all trials. The experiments were conducted on Fanuc CNC lathe and CNMG 120408; uncoated carbide cutting tool is used as the insert for all machining operations. The affecting factors and levels selected for turning properties Al6061/12 wt. $\% \mathrm{Al}_{2} \mathrm{O}_{3} / 6$ wt. $\% \mathrm{MoS}_{2}$ are given in Table 4. SR is measured by the Mitutoyo surface roughness tester. The three cutting parameters selected for the present investigation are cutting speed, feed, and depth of cut. Minitab14 statistical software has been used for the analysis of the experimental work.

\section{Result and Discussion}

3.1. Optimum Setting for TS and BHN of Al6061/Al $\mathrm{O}_{3} / \mathrm{MoS}_{2}$. The tensile strength and hardness of the Al6061/4, 8, and 12 wt.\% $\mathrm{Al}_{2} \mathrm{O}_{3} / 2,4$ wt.\% $\mathrm{MoS}_{2}$ hybrid composite are shown in Figures 1(a) and 1(b). It is observed that an addition of alumina particles improves the tensile strength and hardness of hybrid composites. It is evident that tensile strength and hardness clearly increase with the addition of alumina particles. The tensile strength and hardness of the Al6061/4, 8, and 12 wt. $\% \mathrm{Al}_{2} \mathrm{O}_{3} / 6$ wt. $\% \mathrm{MoS}_{2}$ hybrid composites are shown in Figure 1(c). The tensile strength and hardness of hybrid composites were decreased with increasing content of molybdenum disulphide.

The measured values of tensile strength and BHN for $\mathrm{Al} 6061 / \mathrm{Al}_{2} \mathrm{O}_{3} / \mathrm{MoS}_{2}$ under different wt.\% and corresponding signal to noise ratio for all experimental runs are given in Table 5. The Taguchi analyses of tensile strength and BHN for $\mathrm{Al} 6061 / \mathrm{Al}_{2} \mathrm{O}_{3} / \mathrm{MoS}_{2}$ under different wt.\% are given in Table 6. It clearly shows the maximum tensile strength is obtained at 12 wt. $\%$ of $\mathrm{Al}_{2} \mathrm{O}_{3}$ and $2 \mathrm{wt} . \%$ of $\mathrm{MoS}_{2}$ and the maximum $\mathrm{BHN}$ is obtained at $12 \mathrm{wt} . \%$ of $\mathrm{Al}_{2} \mathrm{O}_{3}$ and 4 wt. $\%$ of $\mathrm{MoS}_{2}$. Table 7 shows the results of ANOVA for tensile strength and $\mathrm{BHN}$ on $\mathrm{Al} 6061 / \mathrm{Al}_{2} \mathrm{O}_{3} / \mathrm{MoS}_{2}$ hybrid composite. It is observed that $\mathrm{Al}_{2} \mathrm{O}_{3}$ is the most significant parameter affecting the tensile strength of $\mathrm{Al} 6061 / \mathrm{Al}_{2} \mathrm{O}_{3} / \mathrm{MoS}_{2}$ with $F$ : $P$ value of $1092.26: 0.000$ and $\mathrm{Al}_{2} \mathrm{O}_{3}$ is significantly affecting the $\mathrm{BHN}$ of $\mathrm{Al} 6061 / \mathrm{Al}_{2} \mathrm{O}_{3} / \mathrm{MoS}_{2}$ with $F: P$ value of 480.69: 0.000 .

3.2. Tribological Behaviour of $\mathrm{Al} 6061 / \mathrm{Al}_{2} \mathrm{O}_{3} / \mathrm{MoS}_{2}$. The variation of wear rate for $\mathrm{Al} 6061 / 12 \mathrm{wt} . \% \mathrm{Al}_{2} \mathrm{O}_{3} / \mathrm{MoS}_{2}$ hybrid composite with respect to different sliding velocity and applied load is shown in Figures 2(a), 2(b), and 2(c). The applied load affects the wear rate of hybrid composites significantly. The wear rate varying with applied load is an indicative of Archard's law and significantly lower in the case of hybrid composites. The wear rate increases with increasing applied load and it is less at $6 \mathrm{wt} . \%$ of $\mathrm{MoS}_{2}$ hybrid composites as compared to $2 \mathrm{wt}$.\% of $\mathrm{MoS}_{2}$ [23]. This is mainly due to the presence of $\mathrm{Al}_{2} \mathrm{O}_{3}$ in $\mathrm{Al} 6061$. However, at all load conditions 
TABLE 3: Affecting factors and levels selected for Tribology Al6061/12 wt. $\% \mathrm{Al}_{2} \mathrm{O}_{3} / \mathrm{MoS}_{2}$.

\begin{tabular}{lccc}
\hline Factors/levels & 1 & 2 & 3 \\
A: load (N) & 15 & 30 & 45 \\
B: sliding velocity (m/s) & 1.25 & 2.50 & 3.25 \\
C: wt.\% of $\mathrm{MoS}_{2}$ (wt.\%) & 2 & 4 & 6 \\
\hline
\end{tabular}

TABLE 4: Affecting factors and levels selected for turning properties Al6061/12 wt. $\% \mathrm{Al}_{2} \mathrm{O}_{3} / 6$ wt. $\% \mathrm{MoS}_{2}$.

\begin{tabular}{lccc}
\hline Factors/levels & 1 & 2 & 3 \\
$V($ cutting speed $(\mathrm{m} / \mathrm{min}))$ & 100 & 150 & 200 \\
$F($ feed $(\mathrm{mm} / \mathrm{rev}))$ & 0.1 & 0.2 & 0.3 \\
$D($ depth of cut $(\mathrm{mm}))$ & 1 & 1.5 & 2 \\
\hline
\end{tabular}

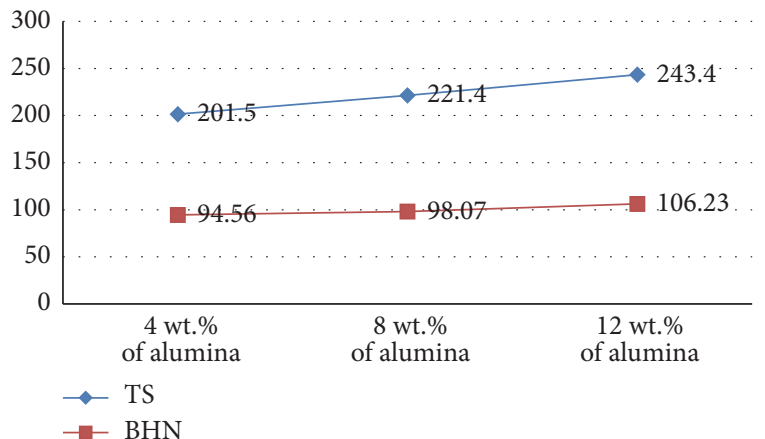

(a)

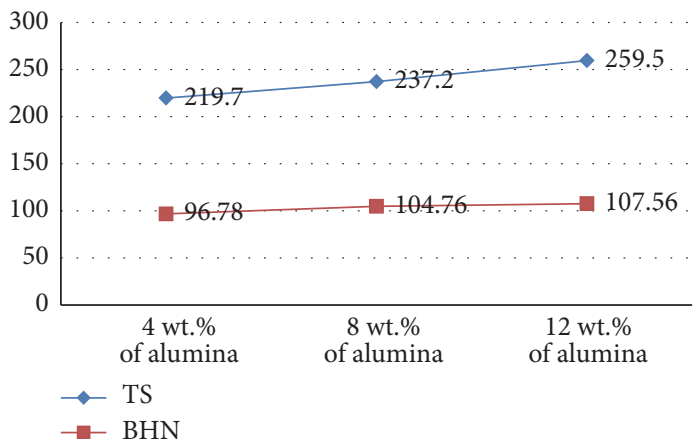

(b)

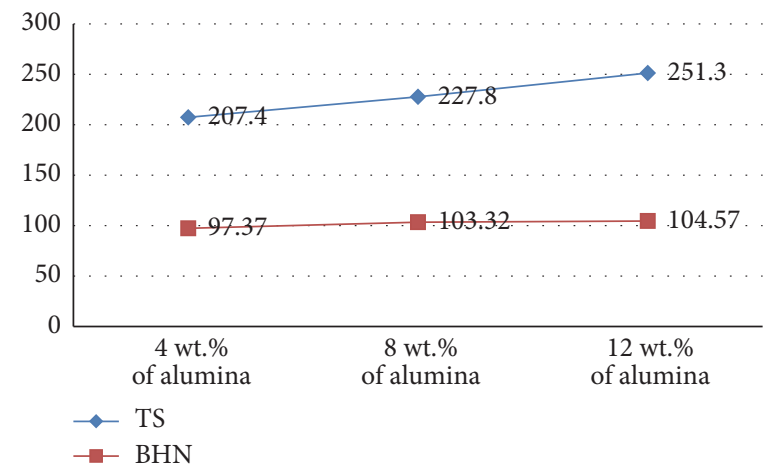

(c)

Figure 1: (a) Mechanical behaviour of Al6061/2 wt.\% of $\mathrm{MoS}_{2} / 4: 8: 12$ wt.\% of $\mathrm{Al}_{2} \mathrm{O}_{3}$. (b) Mechanical behaviour of Al6061/4 wt.\% of $\mathrm{MoS}_{2} / 4: 8: 12$ wt. $\%$ of $\mathrm{Al}_{2} \mathrm{O}_{3}$. (c) Mechanical behaviour of Al6061/6 wt. $\%$ of $\mathrm{MoS}_{2} / 4: 8: 12$ wt. $\%$ of $\mathrm{Al}_{2} \mathrm{O}_{3}$.

TABLE 5: Experimental result for tensile strength of $\mathrm{Al} 6061 / \mathrm{Al}_{2} \mathrm{O}_{3} / \mathrm{MoS}_{2}$.

\begin{tabular}{|c|c|c|c|c|c|c|c|c|}
\hline Trial & $X$ & $Y$ & $\mathrm{Al}_{2} \mathrm{O}_{3}$ (wt.\%) & $\mathrm{MoS}_{2}$ (wt.\%) & $\mathrm{TS}\left(\mathrm{N} / \mathrm{mm}^{2}\right)$ & $\mathrm{S} / \mathrm{N}$ ratio & $\mathrm{BHN}$ & $\mathrm{S} / \mathrm{N}$ ratio \\
\hline 1 & 1 & 1 & 4 & 2 & 201.5 & 46.0855 & 94.56 & 33.2713 \\
\hline 2 & 1 & 2 & 4 & 4 & 219.7 & 46.8366 & 96.78 & 33.4117 \\
\hline 3 & 1 & 3 & 4 & 6 & 207.4 & 46.3362 & 97.37 & 33.3184 \\
\hline 4 & 2 & 1 & 8 & 2 & 221.4 & 46.9036 & 98.67 & 33.4241 \\
\hline 5 & 2 & 2 & 8 & 4 & 237.2 & 47.5023 & 104.76 & 33.5343 \\
\hline 6 & 2 & 3 & 8 & 6 & 227.8 & 47.1511 & 103.32 & 33.4698 \\
\hline 7 & 3 & 1 & 12 & 2 & 243.4 & 47.7264 & 106.23 & 33.5752 \\
\hline 8 & 3 & 2 & 12 & 4 & 259.5 & 48.2827 & 107.56 & 33.6758 \\
\hline 9 & 3 & 3 & 12 & 6 & 251.3 & 48.0038 & 104.57 & 33.6255 \\
\hline
\end{tabular}


TABLE 6: Taguchi analysis: TS \& BHN versus $X, Y$ of $\mathrm{Al} 6061 / \mathrm{Al}_{2} \mathrm{O}_{3} / \mathrm{MoS}_{2}$.

\begin{tabular}{|c|c|c|c|c|}
\hline \multirow{2}{*}{ Level } & \multicolumn{2}{|c|}{ TS } & \multicolumn{2}{|c|}{$\mathrm{BHN}$} \\
\hline & $X$ & $Y$ & $X$ & $Y$ \\
\hline 1 & 46.42 & 46.91 & 33.33 & 33.42 \\
\hline 2 & 47.19 & 47.54 & 33.48 & 33.54 \\
\hline 3 & 48.00 & 47.16 & 33.63 & 33.47 \\
\hline Delta & 1.58 & 0.64 & 0.29 & 0.12 \\
\hline Rank & 1 & 2 & 1 & 2 \\
\hline
\end{tabular}

TABLE 7: Analysis of variance for TS \& $\mathrm{BHN}$ of $\mathrm{Al} 6061 / \mathrm{Al}_{2} \mathrm{O}_{3} / \mathrm{MoS}_{2}$.

\begin{tabular}{|c|c|c|c|c|c|c|c|c|c|}
\hline \multirow{2}{*}{ Source } & \multirow{2}{*}{$\mathrm{DF}$} & \multicolumn{4}{|c|}{ TS } & \multicolumn{4}{|c|}{$\mathrm{BHN}$} \\
\hline & & Seq SS & Adj MS & $F$ & $P$ & Seq SS & Adj MS & $F$ & $P$ \\
\hline$X$ & 2 & 2634.78 & 1317.39 & 1092.26 & 0.000 & 3.7691 & 1.8845 & 480.69 & 0.000 \\
\hline Y & 2 & 423.56 & 211.78 & 175.59 & 0.000 & 0.6125 & 0.3063 & 78.12 & 0.001 \\
\hline Error & 4 & 4.82 & 1.21 & & & 0.0157 & 0.0039 & & \\
\hline Total & 8 & 3063.17 & & & & 4.3973 & & & \\
\hline \multicolumn{6}{|c|}{$R^{2}=99.84 \% ; R^{2}($ adj $)=99.69 \%$} & \multicolumn{4}{|c|}{$R^{2}=99.64 \% ; R^{2}(\operatorname{adj})=99.29 \%$} \\
\hline
\end{tabular}

considered, the wear resistance of the hybrid composites is superior to the matrix alloy. The wear rate is increased with increase in sliding speed Al6061/12 wt. $\% \mathrm{Al}_{2} \mathrm{O}_{3} / \mathrm{MoS}_{2}$ hybrid composite. Increasing sliding speed temperature is raised to the sliding surfaces; this leads to softening of the matrix and composite pin surfaces and it is due to the enhancement in the hardness. The increase in hybrid composite hardness results in improvement of wear resistance. The presence of $\mathrm{MoS}_{2}$ and $\mathrm{Al}_{2} \mathrm{O}_{3}$ particles in the hybrid composite will lead to further reduction of wear rate [24].

The coefficient of friction for $\mathrm{Al} 061 / 12$ wt. $\% \mathrm{Al}_{2} \mathrm{O}_{3} / \mathrm{MoS}_{2}$ hybrid composites under varying load and sliding velocity is shown in Figures 3(a), 3(b), and 3(c). The coefficient of friction is decreased with increasing wt.\% of $\mathrm{MoS}_{2}$ and increasing the due to load. The $\mathrm{Al}_{2} \mathrm{O}_{3}$ particles act as load bearing elements in the hybrid composites and also this results in formation of more stable lubricating film on the tribosurface of the hybrid composites. The decreased coefficient of friction of hybrid composite with $\mathrm{MoS}_{2}$ content can be credited to the collective effects of $\mathrm{MoS}_{2}$ and $\mathrm{Al}_{2} \mathrm{O}_{3}$ particles in formation of a more resistant tribolayer on the contact surface. The graphite tribofilm minimizes the degree of shear stress transferred to the sliding material underneath the sliding contact area which results in less plastic deformation in the subsurface region and reduces the wear rate in the hybrid composites [25].

3.3. Effect of Alumina and Molybdenum Disulfide Content in Al6061. The wear surface of the Al6061/12 wt.\% $\mathrm{Al}_{2} \mathrm{O}_{3} / 6$ wt. $\% \mathrm{MoS}_{2}$ under sliding velocity of $2.50 \mathrm{~m} / \mathrm{sec}$ is given in Figures 4(a) and 4(b). It clearly reveals the formation of tribolayer on the contact surfaces of aluminum composites tested at $15 \mathrm{~N}$ and $45 \mathrm{~N}$ conditions. Figure 4 (a) reveals that the tribolayer is formed only to a limited extent in Al6061/12 wt.\%
$\mathrm{Al}_{2} \mathrm{O}_{3} / 4$ wt. $\% \mathrm{MoS}_{2}$ hybrid composite at $15 \mathrm{~N}$ load, $2.50 \mathrm{~m} / \mathrm{s}$ sliding speed. At a higher load of $45 \mathrm{~N}$ and $2.50 \mathrm{~m} / \mathrm{s}$ sliding speed the tribolayer that is formed increases, due to squeezing out of solid lubricant from the hybrid composites. The extent of tribolayer formation also increases with increasing percentage of molybdenum disulphide located immediately below the contact surface.

The experimental values of wear rate and coefficient of friction for Al6061/12 wt. $\% \mathrm{Al}_{2} \mathrm{O}_{3} / \mathrm{MoS}_{2}$ under different parameters and corresponding signal to noise ratio for all experimental runs are given in Table 8 . The Taguchi analysis for Al6061/12 wt.\% $\mathrm{Al}_{2} \mathrm{O}_{3} / \mathrm{MoS}_{2}$ under different load, sliding velocity, and wt.\% of $\mathrm{MoS}_{2}$ is given in Table 9. It clearly shows the minimum wear rate and coefficient of friction is obtained at $15 \mathrm{~N}$ of load, $3.25 \mathrm{~m} / \mathrm{sec}$ of sliding velocity, and $6 \mathrm{wt} . \%$ of $\mathrm{MoS}_{2}$. Table 10 shows the results of ANOVA for wear rate and coefficient of friction on Al6061/12 wt. $\% \mathrm{Al}_{2} \mathrm{O}_{3} / \mathrm{MoS}_{2}$ hybrid composite. It is observed that load is the most significant parameter affecting the wear rate and coefficient of friction of Al6061/12 wt. $\% \mathrm{Al}_{2} \mathrm{O}_{3} / \mathrm{MoS}_{2}$ with $F: P$ value of $29.06: 0.033$ and $756.27: 0.001$.

3.4. Optimum Setting for CNC Tuning Al6061/12wt.\% $\mathrm{Al}_{2} \mathrm{O}_{3} / 6 \mathrm{wt}$.\% $\mathrm{MoS}_{2}$. The experimental results of arithmetic mean value for turning Al6061/12 wt. $\% \mathrm{Al}_{2} \mathrm{O}_{3} / 6$ wt. $\% \mathrm{MoS}_{2}$ under different cutting conditions and corresponding signal to noise ratio for all experimental runs are given in Table 11. The Taguchi analysis for Al6061/12 wt. $\% \mathrm{Al}_{2} \mathrm{O}_{3} / 6$ wt. $\% \mathrm{MoS}_{2}$ using uncoated carbide cutting tool is given in Table 12. It clearly shows the minimum surface roughness is obtained at $100 \mathrm{~m} / \mathrm{min}$ of cutting speed, $0.1 \mathrm{~mm} / \mathrm{rev}$ of feed, and $1.5 \mathrm{~mm}$ of depth of cut for tuning Al6061/12 wt.\% $\mathrm{Al}_{2} \mathrm{O}_{3} / 6$ wt.\% $\mathrm{MoS}_{2}$. Table 13 shows the results of ANOVA for surface roughness on Al6061/12 wt. $\% \mathrm{Al}_{2} \mathrm{O}_{3} / 6$ wt.\% $\mathrm{MoS}_{2}$ hybrid 


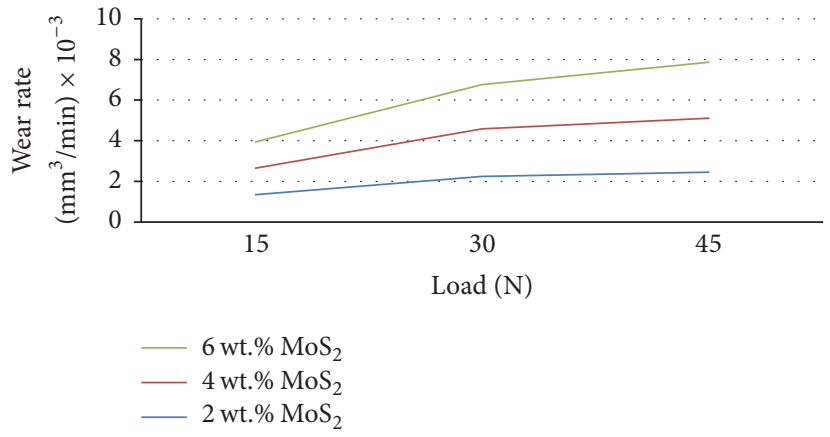

(a)

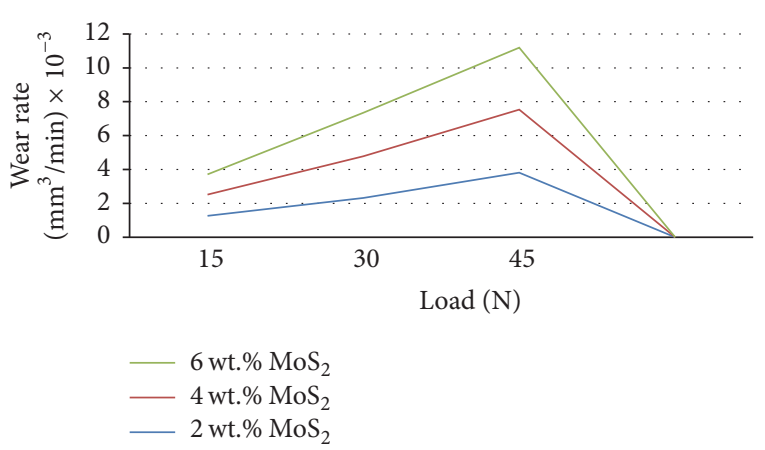

(b)

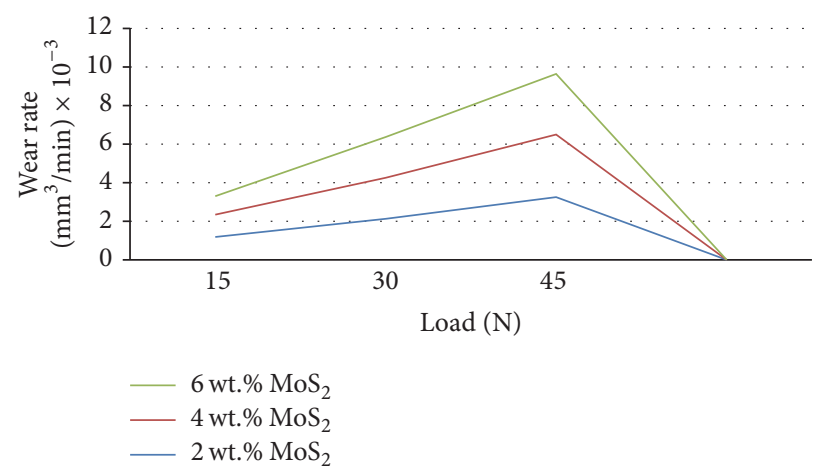

(c)

FIGURE 2: (a) Wear rate of $\mathrm{Al} 6061 / 12 \mathrm{wt} . \% \quad \mathrm{Al}_{2} \mathrm{O}_{3} / \mathrm{MoS}_{2}$ during sliding velocity of $1.25 \mathrm{~m} / \mathrm{sec}$. (b) Wear rate of $\mathrm{Al} 6061 / 12 \mathrm{wt} . \%$ $\mathrm{Al}_{2} \mathrm{O}_{3} / \mathrm{MoS}_{2}$ during sliding velocity of $2.50 \mathrm{~m} / \mathrm{sec}$. (c) Wear rate of Al6061/12 wt. $\% \mathrm{Al}_{2} \mathrm{O}_{3} / \mathrm{MoS}_{2}$ during sliding velocity of $3.25 \mathrm{~m} / \mathrm{sec}$.

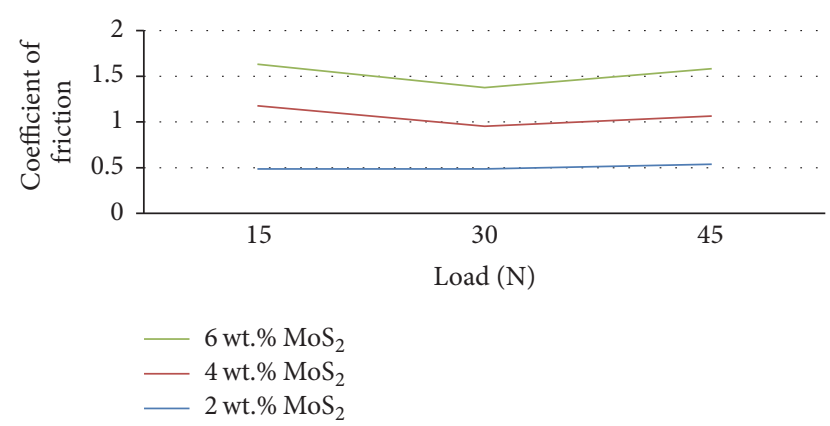

(a)

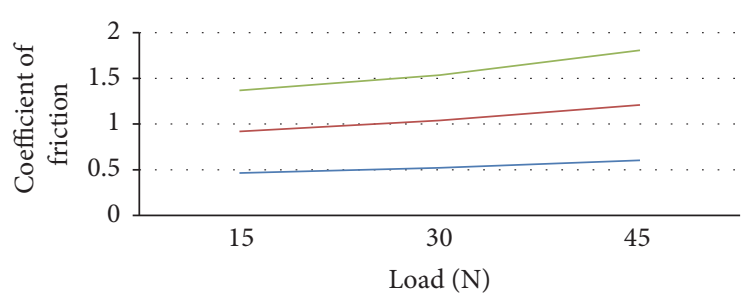

- 6 wt. $\% \mathrm{MoS}_{2}$

- 4 wt. $\% \mathrm{MoS}_{2}$

- 2 wt. $\% \mathrm{MoS}_{2}$

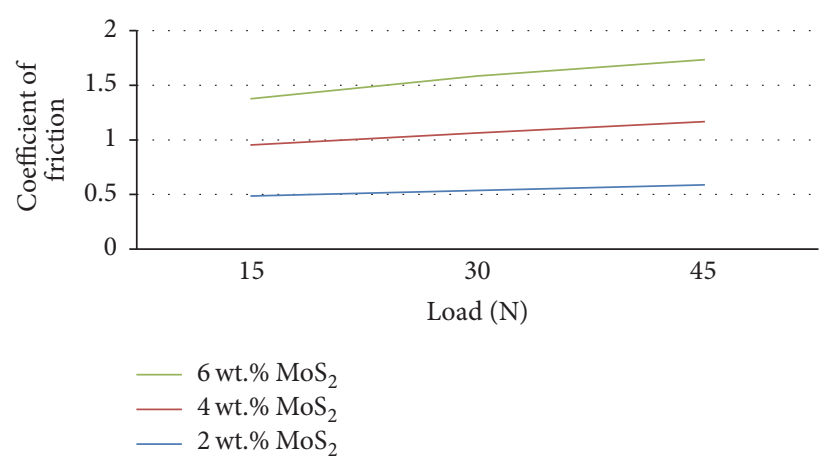

(c)

Figure 3: (a) Coefficient of friction of Al6061/12 wt.\% $\mathrm{Al}_{2} \mathrm{O}_{3} / \mathrm{MoS}_{2}$ during sliding velocity of $1.25 \mathrm{~m} / \mathrm{sec}$. (b) Coefficient of friction of Al6061/12 wt.\% $\mathrm{Al}_{2} \mathrm{O}_{3} / \mathrm{MoS}_{2}$ during sliding velocity of $2.50 \mathrm{~m} / \mathrm{sec}$. (c) Coefficient of friction of $\mathrm{Al} 6061 / 12 \mathrm{wt} . \% \mathrm{Al}_{2} \mathrm{O}_{3} / \mathrm{MoS}_{2}$ during sliding velocity of $3.25 \mathrm{~m} / \mathrm{sec}$. 
TABLE 8: Experimental results for Al6061/12 wt.\% $\mathrm{Al}_{2} \mathrm{O}_{3} / \mathrm{MoS}_{2}$ of wear study.

\begin{tabular}{|c|c|c|c|c|c|c|c|c|c|c|}
\hline Trial & $A$ & $B$ & C & Load $(\mathrm{N})$ & Sliding velocity $(\mathrm{m} / \mathrm{s})$ & wt. $\%$ of $\mathrm{MoS}_{2}$ (wt.\%) & $\begin{array}{c}\text { Wear rate } \\
\left(\mathrm{mm}^{3} / \mathrm{min}\right) \times 10^{-3}\end{array}$ & $\mathrm{~S} / \mathrm{N}$ & Coefficient of friction & $\mathrm{S} / \mathrm{N}$ \\
\hline 1 & 1 & 1 & 1 & 15 & 1.25 & 2 & 1.346 & -2.580 & 0.487 & 6.249 \\
\hline 2 & 1 & 2 & 2 & 15 & 2.50 & 4 & 1.250 & -1.938 & 0.455 & 6.839 \\
\hline 3 & 1 & 3 & 3 & 15 & 3.25 & 6 & 0.966 & 0.300 & 0.423 & 7.473 \\
\hline 4 & 2 & 1 & 2 & 30 & 1.25 & 4 & 2.344 & -7.399 & 0.523 & 5.629 \\
\hline 5 & 2 & 2 & 3 & 30 & 2.50 & 6 & 2.576 & -8.218 & 0.496 & 6.090 \\
\hline 6 & 2 & 3 & 1 & 30 & 3.25 & 2 & 2.133 & -6.579 & 0.537 & 5.400 \\
\hline 7 & 3 & 1 & 3 & 45 & 1.25 & 6 & 2.756 & -8.805 & 0.568 & 4.913 \\
\hline 8 & 3 & 2 & 1 & 45 & 2.50 & 2 & 3.813 & -11.625 & 0.603 & 4.393 \\
\hline 9 & 3 & 3 & 2 & 45 & 3.25 & 4 & 3.245 & -10.224 & 0.579 & 4.746 \\
\hline
\end{tabular}

TABLE 9: Taguchi analysis: wear rate and coefficient of friction versus $A, B$, and $C$ of $A 16061 / 12$ wt. $\% \mathrm{Al}_{2} \mathrm{O}_{3} / \mathrm{MoS}_{2}$.

\begin{tabular}{lcccccc}
\hline \multirow{2}{*}{ Level } & & Wear rate & & \multicolumn{3}{c}{ Coefficient of friction } \\
& $A$ & $B$ & $C$ & $A$ & \multicolumn{2}{c}{$B$} \\
\hline 1 & $-\mathbf{1 . 4 0 6}$ & -6.262 & -6.929 & $\mathbf{6 . 8 5 4}$ & 5.597 & 5.348 \\
2 & -7.399 & -7.261 & -6.521 & 5.707 & 5.775 & 5.739 \\
3 & -10.218 & $-\mathbf{5 . 5 0 1}$ & $-\mathbf{5 . 5 7 5}$ & 4.684 & $\mathbf{5 . 8 7 3}$ & $\mathbf{6 . 1 5 9}$ \\
Delta & 8.812 & 1.760 & 1.354 & 2.170 & 0.276 & 3 \\
Rank & 1 & 2 & 3 & 1 & 3 \\
\hline
\end{tabular}

TABLE 10: Analysis of variance for wear rate of $\mathrm{Al} 6061 / 12 \mathrm{wt} . \% \mathrm{Al}_{2} \mathrm{O}_{3} / \mathrm{MoS}_{2}$.

\begin{tabular}{|c|c|c|c|c|c|c|c|c|c|}
\hline \multirow[b]{2}{*}{ Source } & \multirow[b]{2}{*}{$D F$} & \multicolumn{4}{|c|}{ Wear rate } & \multicolumn{4}{|c|}{ Coefficient of friction } \\
\hline & & Seq SS & Adj MS & $F$ & $P$ & Seq SS & Adj MS & F & $P$ \\
\hline$A$ & 2 & 6.5442 & 3.2721 & 29.06 & 0.033 & 0.0247047 & 0.0123523 & 756.27 & 0.001 \\
\hline$B$ & 2 & 0.3456 & 0.1728 & 1.53 & 0.395 & 0.0002580 & 0.0001290 & 7.90 & 0.112 \\
\hline C & 2 & 0.1651 & 0.0826 & 0.73 & 0.577 & 0.0032667 & 0.0016333 & 100.00 & 0.010 \\
\hline Error & 2 & 0.2252 & 0.1126 & & & 0.0000327 & 0.0000327 & & \\
\hline Total & 8 & 7.2801 & & & & 0.0282620 & & & \\
\hline \multicolumn{6}{|c|}{$R^{2}=96.91 \% ; R^{2}($ adj $)=87.63 \%$} & \multicolumn{4}{|c|}{$R^{2}=99.88 \% ; R^{2}(\operatorname{adj})=99.54 \%$} \\
\hline
\end{tabular}

TABLE 11: Experimental result of surface roughness for Al6061/12 wt. $\% \mathrm{Al}_{2} \mathrm{O}_{3} / 6$ wt.\% $\mathrm{MoS}_{2}$.

\begin{tabular}{|c|c|c|c|c|c|c|c|c|}
\hline Trial & $V$ & $F$ & $D$ & $V$ & $F$ & $D$ & $\mathrm{Ra}(\mu \mathrm{m})$ & $\mathrm{S} / \mathrm{N}$ ratio \\
\hline 1 & 1 & 1 & 1 & 100 & 0.1 & 1 & 2.21 & -6.887 \\
\hline 2 & 1 & 2 & 2 & 100 & 0.2 & 1.5 & 2.35 & -7.421 \\
\hline 3 & 1 & 3 & 3 & 100 & 0.3 & 2 & 3.56 & -11.029 \\
\hline 4 & 2 & 1 & 2 & 150 & 0.1 & 1.5 & 2.48 & -7.889 \\
\hline 5 & 2 & 2 & 3 & 150 & 0.2 & 2 & 2.65 & -8.464 \\
\hline 6 & 2 & 3 & 1 & 150 & 0.3 & 1 & 3.62 & -11.174 \\
\hline 7 & 3 & 1 & 3 & 200 & 0.1 & 2 & 2.88 & -9.187 \\
\hline 8 & 3 & 2 & 1 & 200 & 0.2 & 1 & 3.02 & -9.600 \\
\hline 9 & 3 & 3 & 2 & 200 & 0.3 & 1.5 & 3.87 & -11.754 \\
\hline
\end{tabular}

TABLE 12: Taguchi analysis: Ra versus $V, F$, and $D$ for Al6061/12 wt. $\% \mathrm{Al}_{2} \mathrm{O}_{3} / 6$ wt. $\% \mathrm{MoS}_{2}$.

\begin{tabular}{lccc}
\hline Level & $V$ & $F$ & $D$ \\
\hline 1 & $\mathbf{- 8 . 4 4 6}$ & $-\mathbf{7 . 9 8 8}$ & -9.221 \\
2 & -9.176 & -8.495 & $-\mathbf{9 . 0 2 2}$ \\
3 & -10.181 & -11.319 & -9.561 \\
Delta & 1.735 & 3.331 & 0.539 \\
Rank & 2 & 1 & 3 \\
\hline
\end{tabular}




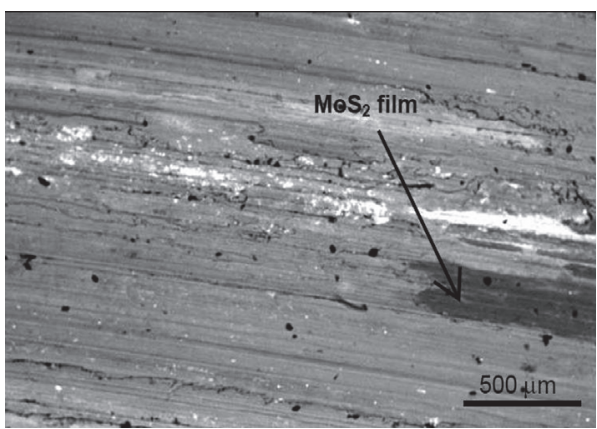

(a)

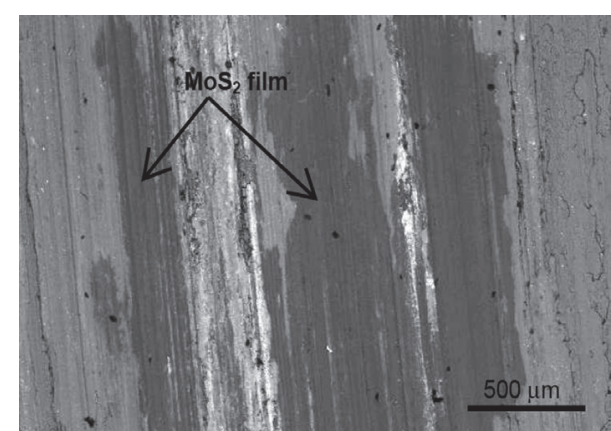

(b)

Figure 4: (a) Wear surface of $\mathrm{Al} 6061 / 12$ wt. $\% \mathrm{Al}_{2} \mathrm{O}_{3} / 6$ wt. $\% \mathrm{MoS}_{2}$ tested at $15 \mathrm{~N}$ load. (b) Wear surface of $\mathrm{Al} 6061 / 12$ wt. $\% \mathrm{Al}_{2} \mathrm{O}_{3} / 6$ wt. $\% \mathrm{MoS}_{2}$ tested at $45 \mathrm{~N}$ load.

TABLE 13: Analysis of variance for $\mathrm{Ra}$ of $\mathrm{Al} 6061 / 12$ wt. $\% \mathrm{Al}_{2} \mathrm{O}_{3} / 6$ wt. $\% \mathrm{MoS}_{2}$.

\begin{tabular}{|c|c|c|c|c|c|c|}
\hline Source & DF & Seq SS & Adj SS & Adj MS & $F$ & $P$ \\
\hline$V$ & 2 & 0.46220 & 0.46220 & 0.23110 & 24.85 & 0.039 \\
\hline$F$ & 2 & 2.38820 & 2.38820 & 1.19410 & 128.40 & 0.008 \\
\hline$D$ & 2 & 0.02580 & 0.02580 & 0.01290 & 1.39 & 0.419 \\
\hline Error & 2 & 0.01860 & 0.01860 & 0.00930 & & \\
\hline Total & 8 & 2.89480 & & & & \\
\hline \multicolumn{7}{|c|}{$S=0.0964365 ; R^{2}=99.36 \% ; R^{2}(\mathrm{adj})=97.43 \%$} \\
\hline
\end{tabular}

composite. It is observed that feed is the most significant parameter affecting the surface roughness of Al6061/12 wt.\% $\mathrm{Al}_{2} \mathrm{O}_{3} / 6$ wt. $\% \mathrm{MoS}_{2}$ with $F: P$ value of $128.40: 008$.

\section{Conclusion}

In the present investigation, the $\mathrm{Al} 6061 / \mathrm{Al}_{2} \mathrm{O}_{3} / \mathrm{MoS}_{2}$ hybrid composite is successfully fabricated using stir casting process. The mechanical behaviour, tribological behaviour, and machinability behaviour are evaluated. The obtained results can be summarized as follows:

(i) Mechanical properties of hybrid composites increase with an increase in weight fraction of alumina particles. An increase in weight fraction of molybdenum disulphide reinforcement decreases the mechanical properties like tensile strength and BHN. The optimum parameter for maximization of tensile strength is obtained at $12 \mathrm{wt} . \%$ of $\mathrm{Al}_{2} \mathrm{O}_{3}$ and $2 \mathrm{wt} . \%$ of $\mathrm{MoS}_{2}$ and the maximum $\mathrm{BHN}$ is obtained at $12 \mathrm{wt} . \%$ of $\mathrm{Al}_{2} \mathrm{O}_{3}$ and 4 wt.\% of $\mathrm{MoS}_{2}$.

(ii) The incorporation of $\mathrm{Al}_{2} \mathrm{O}_{3}$ reinforcement to Al6061 increases the wear resistance of the composites. The addition of $\mathrm{MoS}_{2}$ reinforcement in $\mathrm{Al} 6061 / \mathrm{Al}_{2} \mathrm{O}_{3}$ composites as a hybrid reinforcement further increases the wear and friction resistance of the composite. This is attributed to the stable and $\mathrm{MoS}_{2}$ rich mechanically mixed layer, which prevents metal to metal contact and reduces the wear of the composite. The unstable mechanically mixed layer in the absence of the lubricant phase leads to lower wear resistance in $\mathrm{Al} 6061 / \mathrm{Al}_{2} \mathrm{O}_{3} / \mathrm{MoS}_{2}$ hybrid composite.
The optimum parameter for minimization wear rate and coefficient of friction are obtained at $15 \mathrm{~N}$ of load, $3.25 \mathrm{~m} / \mathrm{sec}$ of sliding velocity, and $6 \mathrm{wt}$. $\%$ of $\mathrm{MoS}_{2}$.

(iii) The optimum parameter for minimization surface roughness is obtained at $100 \mathrm{~m} / \mathrm{min}$ of cutting speed, $0.1 \mathrm{~mm} / \mathrm{rev}$ of feed, and $1.5 \mathrm{~mm}$ of depth of cut for CNC turning Al6061/12 wt.\% $\mathrm{Al}_{2} \mathrm{O}_{3} / 6$ wt.\% $\mathrm{MoS}_{2}$ hybrid composite.

\section{Competing Interests}

The authors declare that they have no competing interests.

\section{References}

[1] L. Poovazhagan, K. Kalaichelvan, A. Rajadurai, and V. Senthilvelan, "Characterization of hybrid silicon carbide and boron carbide nano particles reinforced aluminum alloy composites," Procedia Engineering, vol. 64, pp. 681-689, 2013.

[2] A. M. Al-Qutub, A. Khalil, N. Saheb, and A. S. Hakeem, "Wear and friction behavior of Al6061 alloy reinforced with carbon nanotubes," Wear, vol. 297, no. 1-2, pp. 752-761, 2013.

[3] K. Umanath, K. Palanikumar, and S. T. Selvamani, "Analysis of dry sliding wear behaviour of $\mathrm{Al} 6061 / \mathrm{SiC} / \mathrm{Al}_{2} \mathrm{O}_{3}$ hybrid metal matrix composites," Composites Part B: Engineering, vol. 53, pp. 159-168, 2013.

[4] K. Umanath, ST. Selvamani, and K. Palanikumar, "Friction and wear behaviour of Al6061alloy (SiCp/Alp) hybrid composite," International Journal of Engineering Science and Technology, vol. 3, pp. 5441-5551, 2011.

[5] G. B. Veeresh Kumar, C. S. P. Rao, N. Selvaraj, and M. S. Bhagyashekar, "Studies on $\mathrm{Al} 6061 / \mathrm{SiC}$ and $\mathrm{Al} 7075 / \mathrm{Al}_{2} \mathrm{O}_{3}$ metal 
matrix composites," Journal of Minerals Materials Characterization Engineering, vol. 9, pp. 454-461, 2010.

[6] H. C. Anilkumar, H. S. Hebbar, and K. S. Ravishankar, "Mechanical properties of fly ash reinforced aluminum alloy composites," International Journal of Mechanical and Materials Engineering, vol. 6, pp. 225-233, 2011.

[7] M. Asif, K. Chandra, and P. S. Misra, "Development of aluminum based hybrid metal matrix composites for heavy duty applications," Journal of Minerals and Materials Characterization and Engineering, vol. 10, pp. 115-134, 2011.

[8] D. Singh, H. Singh, S. Kumar, and G. Singh, "An Experimental investigation of Mechanical behaviour of aluminum by adding $\mathrm{SiC}$ and Alumina," International Journal on Emerging Technologies, vol. 3, pp. 178-184, 2012.

[9] V. N. Gaitonde1, S. R. Karnik, and M. S. Jayaprakash, "Some studies on wear and corrosion properties of $\mathrm{Al} 5083 / \mathrm{Al}_{2} \mathrm{O}_{3}$ /graphite hybrid composites," Journal of Minerals and Materials Characterization and Engineering, vol. 11, pp. 695-703, 2012.

[10] R. Sharanabasappa and B. S. Motgi, "A study on mechanical properties of fly ash and alumina reinforced aluminum alloy (LM25) composites," IOSR Journal of Mechanical and Civil Engineering, vol. 7, pp. 14-21, 2013.

[11] D. Kuma and J. Singh, "Comparative Investigation of Mechanical Properties of aluminum based hybrid metal matrix composites," International Journal of Engineering Research and Applications, vol. 1, pp. 31-36, 2014.

[12] C. C. Wang and B. H. Yan, "Blind-hole drilling of $\mathrm{Al}_{2} \mathrm{O}_{3} / 6061 \mathrm{Al}$ composite using rotary electro-discharge machining," Journal of Materials Processing Technology, vol. 102, no. 1, pp. 90-102, 2000.

[13] B. H. Yan and C. C. Wang, "Machining characteristics of $\mathrm{Al}_{2} \mathrm{O}_{3} / 6061 \mathrm{Al}$ composite using rotary electro-discharge machining with a tube electrode," Journal of Materials Processing Technology, vol. 95, no. 1-3, pp. 222-231, 1999.

[14] B. H. Yan, C. C. Wang, W. D. Liu, and F. Y. Huang, "Machining characteristics of $\mathrm{Al}_{2} \mathrm{O}_{3} / 6061 \mathrm{Al}$ composite using rotary EDM with a disklike electrode," International Journal of Advanced Manufacturing Technology, vol. 16, no. 5, pp. 322-333, 2000.

[15] G. B. Veeresh Kumar, C. S. P. Rao, N. Several, and M. S. Bhagyshekar, "Studies on A16061-SiC and Al7075- $\mathrm{Al}_{2} \mathrm{O}_{3}$ metal matrix composites," Journal of Minerals and Materials Characterization \& Engineering, vol. 9, pp. 43-55, 2010.

[16] Y. Sahin, M. Kok, and H. Celik, "Tool wear and surface roughness of $\mathrm{Al}_{2} \mathrm{O}_{3}$ particle-reinforced aluminium alloy composites," Journal of Materials Processing Technology, vol. 128, no. 1-3, pp. 280-291, 2002.

[17] J. P. Davim, "Design of optimisation of cutting parameters for turning metal matrix composites based on the orthogonal arrays," Journal of Materials Processing Technology, vol. 132, no. 1-3, pp. 340-344, 2003.

[18] E. Kiliçkap, O. Çakir, M. Aksoy, and A. Inan, "Study of tool wear and surface roughness in machining of homogenised SiCp reinforced aluminium metal matrix composite," Journal of Materials Processing Technology, vol. 164-165, pp. 862-867, 2005.

[19] A. Metin Kok, "A study on the machinability of $\mathrm{Al}_{2} \mathrm{O}_{3}$ particle reinforced aluminum alloy composite," in Proceedings of the 11th Inorganic Bonded Fiber Composites Conference, vol. 1, pp. 272281, Madrid, Spain, November 2008.

[20] C. A. Brown and M. K. Surappa, "The machinability of a cast aluminium alloy-graphite particle composite," Materials Science and Engineering, vol. 102, no. 1, pp. 31-37, 1988.
[21] M. Kök and K. Özdin, "Wear resistance of aluminium alloy and its composites reinforced by $\mathrm{Al}_{2} \mathrm{O}_{3}$ particles," Journal of Materials Processing Technology, vol. 183, no. 2-3, pp. 301-309, 2007.

[22] H. Kato, M. Takama, Y. Iwai, K. Washida, and Y. Sasaki, "Wear and mechanical properties of sintered copper-in composites containing graphite or molybdenum disulfide," Wear, vol. 255, no. 1-6, pp. 573-578, 2003.

[23] A. Baradeswaran, S. C. Vettivel, A. Elaya Perumal, N. Selvakumar, and R. Franklin Issac, "Experimental investigation on mechanical behaviour, modelling and optimization of wear parameters of $\mathrm{B}_{4} \mathrm{C}$ and graphite reinforced aluminium hybrid composites," Materials and Design, vol. 63, pp. 620-632, 2014.

[24] A. Baradeswaran and A. Elaya Perumal, "Study on mechanical and wear properties of $\mathrm{Al} 7075 / \mathrm{Al}_{2} \mathrm{O}_{3}$ /graphite hybrid composites," Composites Part B: Engineering, vol. 56, pp. 464-471, 2014.

[25] S. Mahdavi and F. Akhlaghi, "Effect of the graphite content on the tribological behavior of $\mathrm{Al} / \mathrm{Gr}$ and $\mathrm{Al} / 30 \mathrm{SiC} / \mathrm{Gr}$ composites processed by in situ powder metallurgy (IPM) method," Tribology Letters, vol. 44, no. 1, pp. 1-12, 2011. 

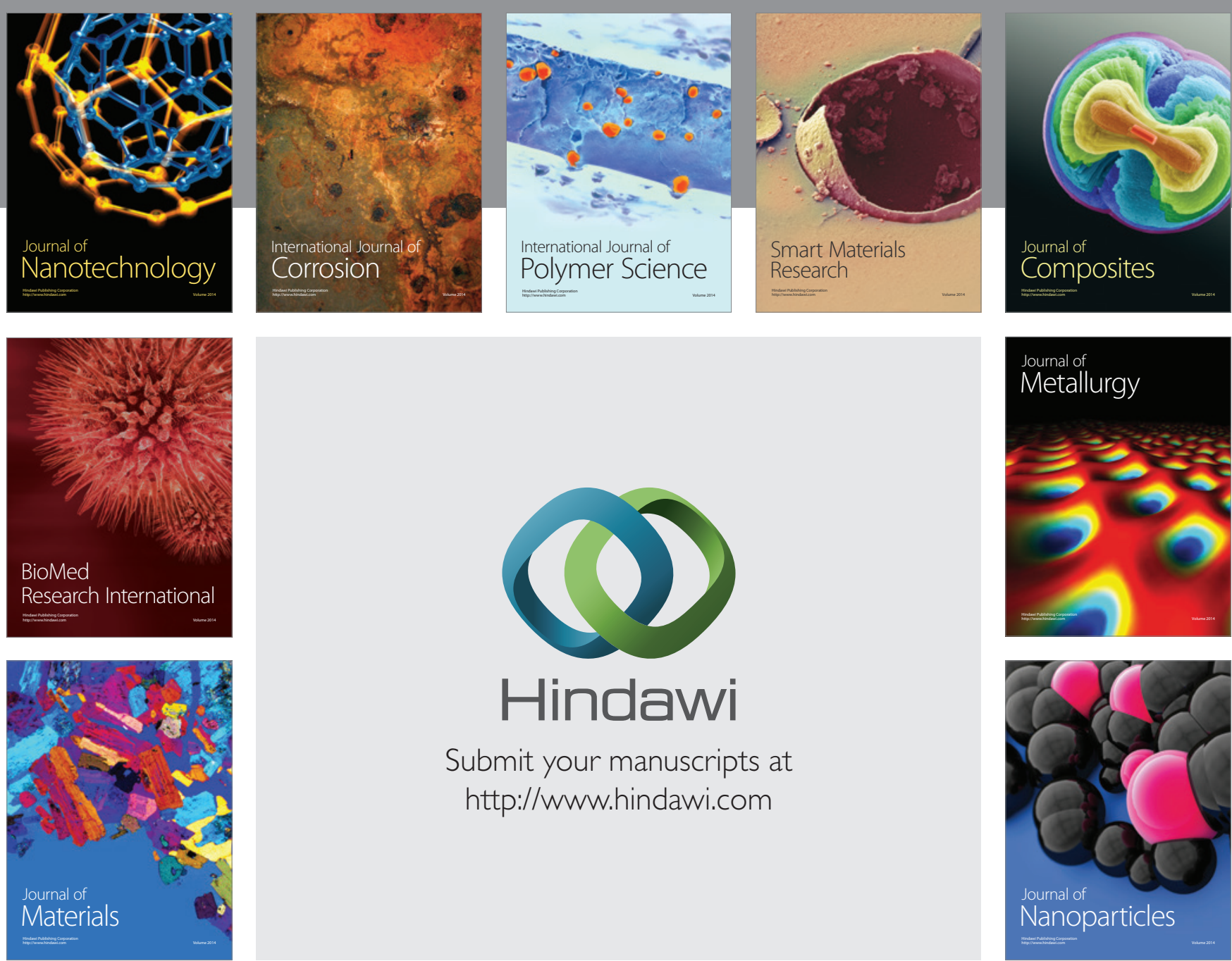

\section{Hindawi}

Submit your manuscripts at

http://www.hindawi.com

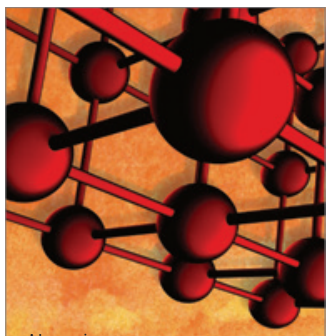

Materials Science and Engineering
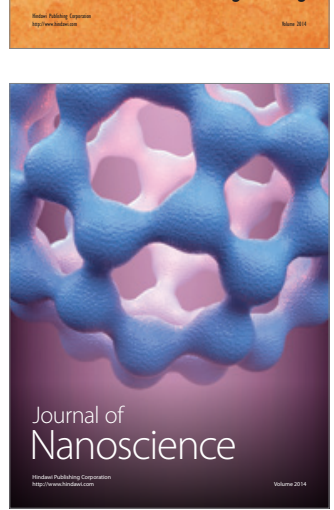
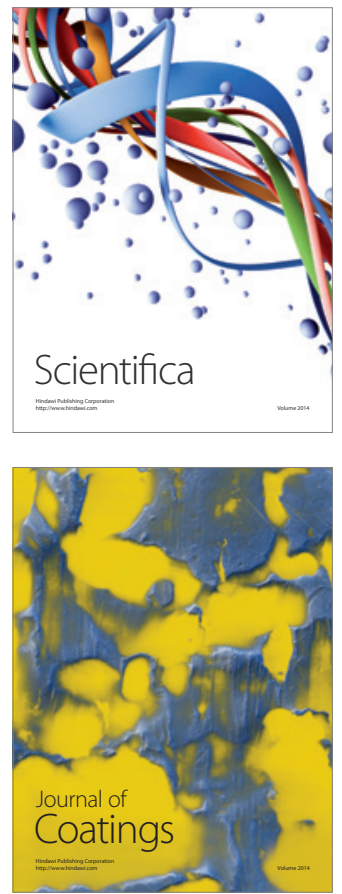
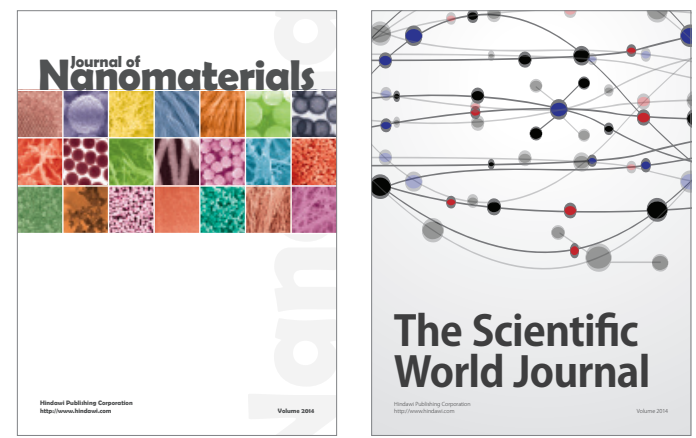

The Scientific World Journal
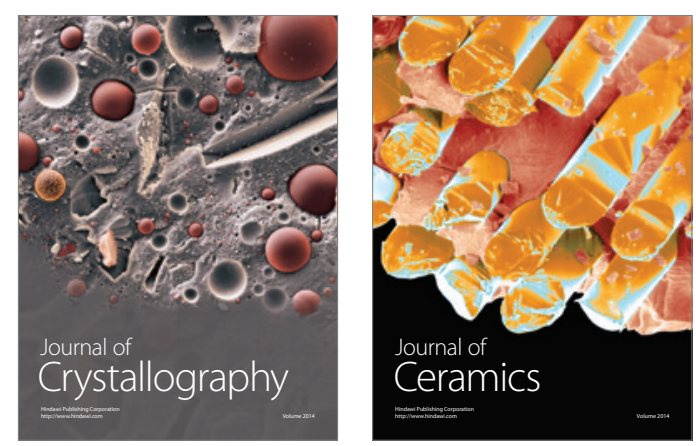
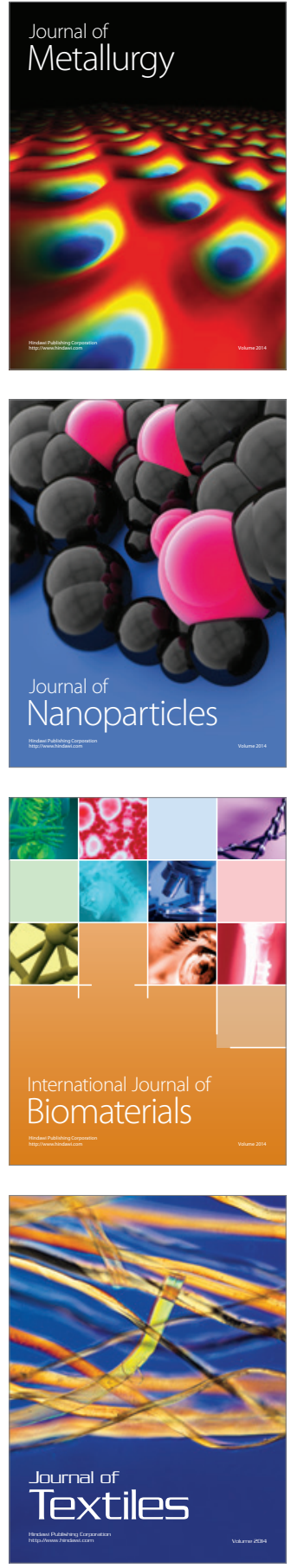